\title{
A FÉL ÉVSZÁZADOS MÚLTÚ FRANCIA TERÜLETFEJLESZTÉS (AMÉNAGEMENT DU TERRITOIRE) ÉS EGY KÖZÉPVÁROS BEMUTA- TÁSA A VÁLTOZÓ PARADIGMÁK FÓKUSZÁBAN
}

\author{
(The Evolution of French Regional Policy [aménagement du \\ territoire] and its Impact on the Development of a Peripheric \\ Mid-size Town)
}

\section{EGYED ILDIKÓ}

Kulcsszavak:

növekedési pólus métropole d'équilibre Párizs ellenpontjai Grenoble technopolisz Minalogic versenyképességi pólus

A tanulmány a François Perroux elméletére alapuló francia növekedési pólus politika tanulságaiból kiindulva jut el a 21. századi Grenoble-i technopolisz és versenyképességi pólus tárgyalásához. A Szerző a felülröl vezényelt növekedési pólus politika elméletével ellentétben kifejti, hogy egy perifẻrikus fekvésü középváros csak úgy válhat térsége számára növekedési centrummá, ha a belső folyamatokat tükrözö városfejlesztési elképzelések és a nemzeti gazdaságpolitikai célok egymással ötvözódnek.

\section{Bevezetés}

Mely területi szintek képezhetik a területfejlesztési politikák fó alanyát egy olyan országban, amelyet a rendkívül nagyfokú területi elaprózottság és sokféleség jellemez? A központi politikák „felkapott” kedvezményezettjei képesek voltak-e beváltani a hozzájuk füzódó sokszor grandiózus és illuzórikus reményeket? Mi az oka az állami politikák gyakori fókuszváltásának, amely befejezetlenségre és töredék megoldásokra enged következtetni? A növekedési pólus politikák fószereplői, a Párizs ellenpólusának tervezett vidéki nagyvárosok vajon képesek voltak-e felzárkózni az európai színvonalú és méretủ metropoliszokhoz? Léteznek-e a növekedés általános receptjekẻnt szolgáló gyógymódok, vagy pedig a vizsgálatokat alulról kell kezdeni, a helyi és specifikus sajátosságok szigorú szem elött tartásával? A választ a két elem ötvözetében kell keresni: erre szolgál a jelen tanulmány második felében szereplö Grenoble technopolisz sajátos fejlődésü miliőjének bemutatása. 


\section{A francia állami növekedési pólus politika}

A felülrỏl jövő állami elképzelések egyoldalúságának illusztrálására szolgál a François Perroux elméletére épülö állami növekedési pólus politikák bemutatása. A területfejlesztés irányítójaként müködő DATAR a hatvanas évek elején a területi kiegyenlítödés grandiózus céljával jelölte ki a nyolc métropole d'équilibre-t, azaz Párizs 300-1000 km-es körzetében fekvő és a fóváros hegemóniáját ellensúlyozó vidéki nagyvárost ${ }^{1}$. A nagyvárosi centrumok versenypozíciójának javulását, voltaképpen a meglévő eröforrások harmonikusabb eloszlását célzó beruházások, az ipari munkahelyek, a tỏke és a lakosság területi átcsoportosítása a várakozások szerint egy kiegyenlítettebb regionális térszerkezet kialakulását eredményezte volna.

A növekedési pólus stratégiák sikertelenségének megértéséhez azok elméleti alapjaihoz - mindenekelött François Perroux definícióihoz kell visszanyúlni. Perroux növekedési pólusként egy olyan ipari komplexumot ír le, amelyben a propulzív (gyakran innovatív) iparág köré csoportosuló vállalatok input-output kapcsolatai további gazdasági növekedést gerjesztenek. A növekedési pólusok létét és egyenlötlen térbeli eloszlását úgy magyarázza Perroux, hogy a növekedés nem általános, pl. egy egész ország területére kiterjedő jelenség, hanem meghatározott földrajzi pontokban (a növekedési pontokban vagy pólusokban) jelenik meg váltakozó intenzitással. Ezek a pontok a gazdasági térben elhelyezkedő növekedési pólusok, vagyis egy adott iparágon vagy szektoron belüli vállalatok tömörülései. A pólusok földrajzi dimenzióban való elhelyezkedésérỏl Perroux csupán azt állítja, hogy a gazdasági tevékenységek területi agglomerációiban egy növekedési pólus versenyképessége és növekedési potenciálja erősödhet (Asheim 1996). Az egy adott szektoron belüli fejlödés paradigmája helyett a francia területfejlesztési gyakorlatban a földrajzi terekre alkalmazták Perroux elméletét, tehát a tervezett növekedési pólusoktól várták a továbbgyürüző növekedés jótékony hatásainak továbbítását térbeli agglomerációjuk, sőt a centrumvárosok hinterlandja felé is.

Különbséget kell tenni a természetes és a tervezett növekedési pólus között. Az elöbbi kifejezés ugyanis minimum 250 ezer foos lakosságú spontán fejlődésủ gazdasági centrumra alkalmazható, az utóbbi pedig a gyakorlati alkalmazásban ennél sokkal kisebb is lehet. A növekedési pólus stratégia sikeres megvalósítása azt jelenti, hogy a tervezett pólus egyre inkább a természetes pólus jegyeit mutatja, melyek a következők: dinamikusan növekvő ipar, az iparágak közötti kapcsolatok intenzitása, nagyfokú tőke és munkaerővonzó képesség, a növekedés spontán természete, a régióban elfoglalt gazdasági és társadalmi súlya (Parr 1999a). Az új beruházások nagy fordista szektorokhoz tartozó ipartelepek létrehozatalát jelentették (autógyártás, vegyipar, acélgyártás). 
A fél évszázados múltú francia területfejlesztés (aménagement du territoire) és egy középváros

bemutatása a változó paradigmák fókuszában. - Tér és Társadalom 23. évf. 2009/1. 167-180. p.

TÉT XXIII. évf. 2009 a 1

Kitekintö

169

A következő alaphiedelmekre támaszkodhatott a központi fejlesztők két évtizeden át népszerü pólusstratégiája:

1) A lemaradó, hátrányos helyzetủ térségekben az ipari zónák, a pénzügyi támogatások és infrastrukturális fejlesztések folytán a támogatásoktól való függőség fokozatosan leépül, a régiók vonzereje megnő.

2) Ha a nagy „nemzeti bajnokok” leányvállalatait sikerül a térben dekoncentrálni, a növekedés eredményei igazságosabb eloszlást fognak mutatni a nemzeti térben.

Az elvárásokkal szemben a megvalósulás egészen más képet mutatott. A kezdeti látványos sikerek (1955-75 közötti periódusban megvalósuló 2745 decentralizációs müvelet, a 429489 új munkahely, 3200 vállalkozás) jelentős eredménynek tekinthetők. Azonban a munkahelyek több mint fele Párizs környékén létesült, míg a kiemelt déli és délnyugati régiókban a munkahelyek negyede, az ipari szerkezetátalakítási gondokkal küzdỏ régiókban pedig csupán 8\%-a. Kevés pólusba települtek stratégiai döntési központok, és a pólusok fỏvárostól való függése nem szủnt meg (Merlin 2007). A pénzügyi támogatásoktól és a nagyszabású infrastrukturális fejlesztésektől várt eredmények nem valósultak meg. Lewin 1965-ben kimutatta, hogy a pólus nagyvárosokban a munkaerő növekedésének aránya alacsonyabb volt, mint a városi hierarchiában utánuk következő szintek városaiban (Parr 1999b). Nem vették figyelembe, hogy az infrastrukturális beruházások egy hátrányos helyzetủ régió problémáinak megoldásához korántsem elegendőek, és hogy a lemaradásért nem csupán a fizikai tőke, hanem a kedvező intézményi, társadalmi és földrajzi feltételek hiánya a felelös.

A pólusokkal szemben megfogalmazott elvárásként szerepelt az is, hogy háttérrégiójuk fejlődését kedvezően befolyásolják. Ezzel szemben a tapasztalatok azt mutatták, hogy a pólus hatása környezetére közömbös (sivatagi katedrális, enklávé, fejlödési sziget), sőt negativ (kilúgozó hatások) is lehetett (Parr 1999b). Negatív, „kilúgozó” hatás akkor lépett fel, ha a növekedési pólus sikeres, alacsony költséggel múködő vállalatai, amelyek fóként régión kívüli piacokra termeltek, háttérrégiójuk korábban a helyi regionális piacra termelỏ kisvállalatait kiszorították a piacról. A sikeres pólusban a háztartások megnövekedett jövedelme miatt a háttérrégió termékei iránti kereslet helyébe a drágább import termékek iránti kereslet lépett. Amennyiben pedig a háttérrégióból a munkaerő a pólusba vándorolt, a helyi közösségek elestek a legprogresszívebb, legnagyobb termelékenységủ elemeiktöl. Súlyosbította a helyzetet, hogy a pólusokban a beruházások javuló feltételei miatt a hinterlandból a tỏke is a pólusokba vándorolt, tovább mélyitve a centrum és periféria közti szakadékot. Legtöbbször a pozitív hatások a régió keretein kívül valósultak meg, a negatív, kilúgozó hatások pedig a régión belül jelentkeztek. Ez azt jelentette, hogy ami előnyös volt a régió egészének, nem feltétlenül kedvezett a háttérrégió igényeinek. Parr (1999b) úgy vélekedik, hogy ha a stratégia készitỏi terveikbe a kompenzációs mechanizmusokat - a régiókon belül a hátrányosan vagy a növekedés által nem érintett térségek kárpótlásának költségeit - is integrálták volna, akkor a stratégia nem vált volna olyan népszerütlenné a kedvezményezettek közé nem tartozó szereplök körében. Ilyen 
intézkedésekre azonban még tervezet sem született, ez jól mutatja, hogy a tervezök nem fordítottak figyelmet a növekedés előnyeinek régión belüli arányos elosztására.

A legnagyobb probléma mégis az volt, hogy a stratégia tervezői figyelmen kívül hagyták a helyi jellegzetességeket, a kijelölt térségekben spontán múködő folyamatokat, támogatott gazdasági tevékenységeket. A stratégia végső bukását a hetvenes évek válságától bekövetkező gazdasági fordulat hozta el. A munkahelyteremtés, a fordista szektorok támogatása a dicsőséges évtizedek gazdasági és demográfiai növekedésének kontextusában nyerhette el létjogosultságát. A hetvenes évek közepétỏl kezdve a DATAR kénytelen volt erőforrásait a dezindusztrializációban érintett régiók válságtüneteinek kezelésére, a több ezer munkahely megszünésének kompenzálására, különféle tüzoltó munkálatokra összpontosítani.

Az ötvenes-hatvanas évek növekedési pólus stratégiái tehát egy adott korszak növekedési kontextusában értelmezhetők, az elért látványos eredmények (a félmillió új munkahely, a 3200 vállalkozás létrehozása) nem csupán a stratégia túlzott egyoldalúsága és Perroux elméletének félreértése miatt, hanem a gazdaság irányváltása következtében sem vezethettek hosszú távú versenyképességhez.

\section{Megváltozott feltételek}

\section{A területfejlesztés paradigmaváltása}

A hatvanas években uralkodó szemlélet a nyolc metropolisz - Párizs ellenpólusainak - fejlesztésétöl kívánta a fóváros hegemóniájának mérséklését megoldani. A területfejlesztési politika céljául a 20. század végére a főbb agglomerációk népességének megkétszereződését, illetve megháromszorozódását tủzte ki. E politika irrealitása mára már igazolódott, hiszen akkor a maival ellentétben magas volt a születések száma (egy nőre átlagosan három gyermek jutott), s a demográfiai növekedés üteme miatt a nagyvárosok felé áramló vándorlás erőteljes volt. Azt, hogy a nemzetközi versenyben a nyolc nagyváros (métropole d'équilibre) fejlődése elmaradt a várt ütemtöl, demográfiai növekedésük középvárosokénál is alacsonyabb üteme mutatja. A nemzetközi városversenyben csupán Lyon, Marseille és Lille érte el a kritikus tömeget ahhoz, hogy (szerényebb módon) felvehesse a versenyt más európai metropoliszokkal. A metropoliszok specializációjára nem került sor, $\mathrm{s}$ a regionális felosztást (22 régió) sem igazították a kiemelt nagyvárosok számához és fejlesztéspolitikájához. A fővárosból a DATAR által irányított autoriter politika célkitúzései pedig nem vették figyelembe a helyi gazdasági miliőt és a helyi politika érdekeit.

A hetvenes években a francia területfejlesztési politika fókuszába a 20-100 ezer fös középvárosok kerültek. E várostípussal szemben olyan követelmények fogalmazódtak meg, mint a vidéki foglalkoztatottak megtartása és fogadása, a nagyvárosokénál kedvezőbb életfeltételek biztosítása, valamint a nagyvárosokból érkező fejlődési impulzusok térségük felé való közvetítése. Az intézkedések a középvárosok szük 
körét érintették, e politikára nagy költségeket nem fordítottak (csupán néhány százmillió frankot). 1983-ban, a decentralizációs törvények évében ez a politika is feledésbe merült. A helyi közösségek pénzügyi autonómiája ugyanis feltételezte, hogy a projektek megvalósítása a városok hatáskörébe kerüljön. A középvárosok fejlesztése - hasonlóan tíz évvel korábban a metropoliszokéhoz - a DATAR fö prioritásai közé került, megszabva a területfejlesztési politika fö irányát, majd ugyanilyen hirtelen feledésbe merült.

A decentralizáció és regionalizmus által fémjelzett nyolcvanas években a városhálózatok fejlesztése került az állami területfejlesztési politikák középpontjába, külföldi példákból merítve az inspirációt (Baden-Würtenberg, Randstad Holland, Emilia-Romagna). Két típusuk jött létre: a középvárosok hálózata, amelyek elhelyezkedésük, helyi potenciáljaik és együttműködési készségük függvényében szervezödtek; valamint az egy nagyváros köré csoportosuló szerveződések (Lille, Lyon, Toulouse, Strasbourg) és azok befolyása alá tartozó városok, amelyek a maguk számára előnyöket kovácsolhattak a fejlődési lehetőségekből. A városhálózatok dinamikáját azonban nagymértékben gátolta, hogy a társuló városok egymással rivalizáltak, és ha a DATAR ösztönzésére hajlandóak is voltak társulni, ez mindenekelött az állam pénzügyi közremúködéséböl való részesedés reményében történt. A pénzügyi autonómia garantálásával az állami területfejlesztési politikát fenyegette a „kétsebességes” regionális fejlődés veszélye: a jelentős erőforrásokkal rendelkezö, nemzetközi versenypozíciókért is harcoló fejlett ipari régiók (île-deFrance, Rhône-Alpes, Provence Alpes-Côte d'Azur), a rurális régiók (Limousin, Auvergne) és az önerőböl való megújulásra képtelen, alacsonyan fejlett ipari régiók (Nord Pas-de-Calais, Lorraine) között mélyülö szakadék.

A nagyfokú centralizációval jellemzett dicsőséges három évtizedet követően az állam szerepe átalakult. Míg a nyolc ellenpólus nagyvárost az állam jelölte ki, és a fejlesztések is centralizált forrásokból valósultak meg, a decentralizáció után a helyi közösségek stratégiai irányaikat és szerveződésüket saját maguk határozták meg. A decentralizációval a helyi közösségek fejlesztéseiben az állam partnerségen alapuló részvételét szerződéses viszonyok fejezik ki (tervszerződések, régióval, a vidéki területekkel, agglomerációkkal, metropoliszokkal kötött szerződései).

A kilencvenes években a klasszikus területfejlesztési politikáról (politique d'aménagement du territoire) eltolódott a hangsúly az endogén, helyi kezdeményezéseket ösztönző területfejlesztési stratégiára. A DATAR a javak kiegyenlített elosztása helyett a térségek szervezödésének feladatát, a redisztributiv területrendezés helyett pedig a "kívánt, szervezett és megosztott” fejlesztéseket helyezte elótérbe; a kilencvenes évek nagyszabású kormányzati vitája a területfejlesztésröl (Aménager la France de 2020) kiemeli, hogy az egyes térségek jövőjét nem kell előkészíteni, hanem hagyni szabadon megvalósulni. E paradigmaváltás a helyi közösségek növekvó szerepére, a döntési kompetenciák helyi szintekre való decentralizációjának szükségére utal. 


\section{A globalizáció hatásai}

A globalizált gazdasági tér részeként, ha egy régió termékeinek versenyképessége csökken, vagy ha versenytársainál alacsonyabb termelékenységi szintet ér el, akkor központi források hiányában elkerülhetetlenül hanyatlásnak indul és elnéptelenedik. Emiatt e régiók számára a versenyképesség fenntartása létkérdéssé vált, vonzerejük megörzése megkívánja, hogy a meglévők mellett folyamatosan újabb tevékenységekre specializálódjanak. A verseny tétje már nem a komparativ, hanem a kompetitív előnyök megszerzése, hiszen a sikeres régiónak a nemzetközi munkamegosztásban való szerepét csak versenyképes termékei és vonzereje garantálják (ellentétben a saját nemzeti valutával rendelkező országokkal, amelyek élhetnek annak leértékelésével, vagy az árak és bérek csökkentésével). A tőke és a termelési tényezők vagy olyan térségek irányába áramolnak, ahol alacsonyak a költségek, vagy amelyekben a magasabb költséget a kiemelkedő hatékonyság és termelékenység kompenzálja, a tér pedig felértékelődik, mint externáliák forrása.

A nyolcvanas évek ,remetropolizációja" fóként az agglomerációk fóvárosainak felértékelődését jelenti, eközben a kis- és közepes városok fejlődése stagnál. Ez a fejlődésbeli divergencia fóként a posztindusztriális gazdaság megjelenésével magyarázható.

\section{A kutatás és az innováció növekvö szerepe}

A posztindusztriális gazdaságban a kutatás és az innováció kiemelt szerepet kap a helyi fejlesztésben. Ezt támasztja alá a versenyképességi és innovációs pólusok, a helyi termelési rendszerek (SPL) és a klaszterek gazdag irodalma. A kutatás hatékonysága annak függvénye, milyen mértékben képes limitált számú versenyképességi pólus köré szervezỏdni (az európai térben mintegy 30). A kiegyenlített területi fejlődés követelménye viszont megkívánja a pólusok térbeli diszperzióját (fóleg a középvárosokban).

A huszadik század végén a $\mathrm{K}+\mathrm{F}$ terén egyre nő Franciaország lemaradása: a regionális kutatási pólusok európai pozíciója gyengül (1995 és 2001 között Párizs - 20-25\%, Rhône-Alpes - 8\%, Midi-Pyrénées - 8\%) (Theys-Bain 2007). A francia kutatások egyszerre magasfokon centralizált (Ile de France területén) és polarizált jellegét mutatja, hogy a tudományos és technológiai hálózat $85 \%$-a csupán hat régióban (Párizs, Bretagne, Rhône-Alpes, Loire vidéke, Midi-Pyrénées, Provence-AlpesCôte-d'Azur) és hat városban koncentrálódik (Párizs és környéke, Brest, Nantes, Lyon, Toulouse, Grenoble) (Theys-Bain 2007).

A francia gazdaság problémáit (technológiai innovációs hátrány, francia termékek skálájának szükülése, a csúcsiparágakban való lemaradás) orvosolandó, 2005-ben megvalósult nagy célokkal kecsegtető versenyképességi pólus programban már nem a DATAR kezdetek óta gyakorolt defenzív „tủzoltó” politikája érvényesül, hanem egy olyan offenziv politika, amely „célul olyan valódi technológiai-gazdasági programok 
A fél évszázados múltú francia területfejlesztés (aménagement du territoire) és egy középváros bemutatása a változó paradigmák fókuszában. - Tér és Társadalom 23. évf. 2009/1. 167-180. p. TÉT XXIII. évf. 2009 a 1

konstruálását tüzte ki, amelyek az ipari, kutatási és a felsőoktatási szférák közti szinergiákra épülnek." (Merlin 2007, 71) A pólusok specializációja a siker alapvető feltétele.

Bár korai még mérleget vonni a közelmúltban indított programról, a problémák közül néhány már körvonalazódni látszik. A pólusok túlzottan nagy száma (67) mellett az egyetemek és a kutatói szféra kapcsolata sok esetben csak szimbolikus jelentőségú, a kijelölt ágazatok nem mindig azok, ahol az innováció a legsürgető́bb, illetve a legelőrehaladottabb; a pólusok specializációja nem mindenhol egyértelmü; a remélt szinergiák nem kellően valósulnak meg; a pólusok földrajzilag nem pontosan definiáltak (egy vagy több régió); a nemzetközi jelentőség követelménye nem teljesül és a pénzügyi eszközök (1500 millió euró a 2006-2008-as időszakra) szétaprózódásának veszélye is fennáll. A pólusok finanszírozásában a DATAR pénzügyi hozzájárulása elenyészö, ez a feladat a helyi közösségekre és más szervekre hárul (gyakran az állam-régió közti szerződések keretén belül) (Merlin 2007).

A DATAR 2003-ban meghirdetett metropoliszok együttmüködésének politikája nem annyira az első urbánus térségek számára jelent újszerủ kihívást (Île de France, Lyon, Marseille, Lille és Toulouse urbánus régiói), hanem a féltucatnyi város számára, amelyek szerényebb méretük miatt nem sorolhatók az európai metropoliszok körébe (Strasbourg, Bordeaux, Nantes, Nice, Montpellier, Grenoble, Rennes), viszont nagyvárosiasodási tendenciáik miatt kiemelkednek a középvárosi agglomerációk sorából. E sajátos helyzetú városok közül jelen írásban Grenoble példáját emeljük ki.

\section{Egy francia hegyvidéki középváros fejlödése a változó ideológiák tükrében}

\section{Az „arany háromszög” és előzményei}

Grenoble történetének nagy részében kis város, szerepe fỏleg katonai és adminisztratív. Vanier (2005) szerint Grenoble sikerének alapja az a folyamatos, nagy gazdasági kilengések nélküli folyamat, amely során a „vízienergia bölcsője” (vaskohászat, elektrokémia), később az elektronikai alkatrészek gyártása (a hetvenes évek végén Merlin Gerin 10 ezer fốt foglalkoztat egy tucatnyi telepen a város térségében), a nukleáris fizika (CENG-CEA betelepedése 1956-ban, ILL 1971-ben, Synchroton 1994-ben), majd az elektronika (Thomson), az informatika (HewlettPackard), a szoftver ipar (Sun System) és végül a nanotechnológiák (STMicroelectronics) területei váltak Grenoble gazdasági életének meghatározóivá.

A technológiai innováció kultúrájának kialakulásánál számos tényezőt kell egyidejűleg figyelembe venni. Mindenekelőtt Grenoble sajátos földrajzi helyzetét. Grenoble hegyek közti fekvése korlátok közé szorítja és be is határolja területi expanzióját: a várost az Alpok láncai minden oldalról körülzárják, megakadályozva az ipari telepek és cégek terjeszkedését, egyúttal gátat szabnak a tömegtermelésnek. A földrajzi adottságok körébe tartozik a hegyekhez kötődö víz, mint a modernitás, a 
hatalom és folyamatos megújulás szimbóluma. A hidroelektromosságra épülö ipari tevékenységek képezték a huszadik század első felében a helyi innovációs rendszer alapját. A múszaki egyetem és a helyi vállalkozások között a 19. század vége óta szoros és termékeny kapcsolatok bázisán épültek ki az informális kapcsolatok szilárd és tartós hálózati rendszerei (Grossetti 1999). A 19. század végétöl kezdve a vízienergiára épülő ipari tevékenységek szoros szinergiában fejlódtek a mérnökképzéssel, s ez a rendkívül szoros kohabitáció szolgált kedvezö táptalajként az ötvenes évekre a nukleáris fizika, informatikai kutatások megjelenésének.

Mivel a városban nem alakult ki a metropoliszokra jellemző pénzügyi (üzleti és kereskedelmi) burzsoázia rétege, az ipari, tudományos és kutató intellektuális elit szabad teret kaphatott a város profiljának meghatározásában. Ennek is évszázados múltja van: az egyetem 1898-ban elhatározta, hogy forrásainak legnagyobb részét az elektromossághoz kapcsolódó müszaki képzés fejlesztésére fordítja (Grossetti 1999). A helyi társadalomban az évszázad során egyre inkább felértékelődött a mérnökök és a kutatók szerepe, ők a városfejlesztés irányítói és a helyi kultúra letéteményesei. A fizika és kapcsolódó kutatások tudományos elitje játszott kiemelkedő szerepet a nagy tudományos komplexumok térségbe vonzásában (CENG - mai nevén CEA-G 1965-ben, CNET 1974-ben, ESRF 1989-ben). Az egyetem-ipar kutatás évszázados múltú arany háromszögét az emberi találékonyság hozta létre, s nagyrészt ennek köszönhetően kapott állami támogatások táplálják az alapkutatásokat és a $\mathrm{K}+\mathrm{F}$ tevékenységeket (nagy nemzeti laboratóriumok betelepedése: $C E N G, I L L$ ).

\section{A tudományos elitista fejlödés szintere: a Grenoble-i technopolisz}

A globális verseny kihívásai miatt felerősödő metropolizáció következményeként a stratégiai tevékenységek a legnagyobb városok között oszlanak meg, másrészt az egy domináns gazdasági centrumból kisugárzó fejlödés helyett csak bizonyos területek értékelődnek fel a többpólusú nagyméretủ urbánus régiókban. Ez a jelenség a szigetcsoportok gazdaságához vezet (Veltz 1996, 147), amely a versenyképességi pólusok vagy innovációs szigetek között funkcionáló hálózatos kapcsolatokra épülö gazdaságot jelenti. Grenoble közel 400 ezer föt számláló agglomerációja, a 721 ezer fós és 243 községből álló urbánus régió (RUG) belsejében nem számít európai méretü metropolisznak, bár annak számos jegyével rendelkezik (1. táblázat).

Miért tartozott mégis az állami politikák kedvezményezettjei közé? Ennek szellemi gyökereibe is érdemes betekinteni.

Ha megvizsgáljuk a 20. század végén létrejött Grenoble-i technopoliszt, minden jegyében megfelel az amerikai Szilikon-völgy prototípusának, vagyis egy csúcstechnológiai inkubátorokká alakult periurbánus övezetnek, ahol a technológiai forradalom termékeként létrejövő utópisztikus közösség tagjaként a modernitás képviselöje, a tudós, az új társadalmi technokrata elit válik a város fejlödésének és arculatának fö megtestesítöjévé. A Grenoble-i technopolisz a technopoliszok többségéhez 
A fél évszázados múltú francia területfejlesztés (aménagement du territoire) és egy középváros bemutatása a változó paradigmák fókuszában. - Tér és Társadalom 23. évf. 2009/1. 167-180. p. TÉT XXIII. évf. 2009 - 1 Kitekintót 175

hasonlóan az informatika-robotika-elektronika, majd a biotechnológia pólusa köré épült ki, amelyek az állami források, a privát szféra, az egyetemi know-how egyesített erőfeszítéseiből jöttek létre a kiválasztott régiókban a technológiai fejlődés és a régió egészének gazdasági növekedése céljából. További közös jellemzőik a munkahelyek gyorsütemü növekedése, a KKV-k nagyarányú jelenléte. A technopoliszok egyetlen ideálban egyesítik a társadalmi haladás motorjaként a kalandvágyó felfedezó hőst, a tudományosság és a technológia képét és az egyéni sikerek megtestesülését. Franciaországban ugyanakkor szülöhelyei is voltak az új technológiai társadalom, az ujj ember születésének, aki kedveli a kockázatot, a szakértelmet, és hisz abban, hogy bármi lehetséges. A mérnök-tudós a modern ember archetípusát testesítette meg, a tettek emberét, aki nem csupán filozófiai és morális gondolkodó, hanem konkrét tudással bír az emberről és tapasztalattal a felelósség és irányítás területén (Wakeman 2003). Utópisztikus urbánus terekként az ellenpólus-városok és utódjaik, a technopoliszok privilegizált helyet foglalnak el a városhierarchiában. Uniform felépítésük, a racionális területrendezés és a szimbolikus építészeti formák a tudományos tevékenységeket kulturális és területi ideál-keretbe foglalják.

\section{TÁBLÁZAT}

$A$ város és agglomerációja jellemzöi

(Grenoble: Territoires et Rangs en France)

\begin{tabular}{lccc}
\hline & Lakosság & Községek & $\begin{array}{c}\text { Nemzeti } \\
\text { pozíció }\end{array}$ \\
\hline Grenoble & 156200 & 1 & 18. \\
Grenoble-Alpes-Métropole & 396800 & 26 & 12. \\
agglomeráció & & & \\
Agglomeráció INSEE & 419300 & 34 & 12. \\
Urbánus régió INSEE & 515000 & 130 & 14. \\
Urbánus régió & 721000 & 243 & 7. \\
\hline
\end{tabular}

Forrás: Vanier (2005).

A technológiai transzfer földrajzi eszközeként szolgáló technopoliszok a tudomány láthatóságát, presztízsét növelik, létrehozva egy elkülönített, differenciált teret az alkalmazott tudományos módszerek, eszközök és gyakorlat legitimációjának céljából. A Grenoble-i technopolisz-program a többi francia példához hasonlóan kifejezi a helyi közösségek önálló építkezésre, az állami gyámkodás alól felszabadulásra irányuló akaratát, saját erőforrásaik és adottságaik előtérbe helyezésével. Ez az akarat egybeesik a decentralizáció és a liberalizmus térhódításával, a helyi képviselöknek azon törekvésével, hogy a technopolisz imázs segitségével a régióközpontokat felélesszék. A legnagyobb nyertesek természetesen a metropoliszok, illetve a gazdag és befolyásos középvárosok, vagyis a hatvanas évek ellenpólus-nagyvárosainak utódjai, amelyek az állam kiváltságos tárgyalófeleiként részt vesznek az iparpolitika meghatározásában. A helyi autonómiát azonban megkérdőjelezi az állami szerepvállalás nagy aránya, amely Grenoble esetében az állami kutatóközpontok jelenlétében $\mathbf{s}$ a külföldi érdekeltségú multinacionális cégek nagy arányában nyilvánul meg. 
A hagyományos centrum-periféria viszonyok felszámolásához a technopolisz programok hozzájárultak, mivel a perifériák felemelkedése egybeesett a fóvárosi kutatóközpontok dekoncentrálásának igényével (kiváltképp az alkalmazott kutatások területén). Ez magyarázza a Grenoble-hoz hasonló technopoliszok, pl. SophiaAntipolis és Toulouse létrejöttét. Általános tapasztalat, hogy a technopoliszok sikere annak fủggvénye, mennyire képesek a teret rendszerré alakítani. Helyi iparpolitikai eszköznek mégsem tekinthetők, mivel a csúcsipar köré nem szerveződik valódi társadalmi-gazdasági egység, sikerük ezért az esedékesség tartományában marad (Rouban 1994). A technopoliszok ellen számos kritika elhangzik. Elsöként említendö, hogy régiójukat legértékesebb humán erőforrásaitól fosztják meg, a centrumperiféria viszonyokat újratermelik, a hatalmi szintek számát bővítik, súlyosbítják az urbánus és a rurális térségek közt feszülő ellentétet. A Párizs és a francia sivatag helyébe a nemzetközi jelentöségü (high-tech) technopolisz övezetek - hagyományos republikánus politikai rendszer ellentéte lép. Az innováció és a modernitás „templomaiként" funkcionáló technopoliszok a szolgáltatások, nemzetközi pénzügyek és a csúcsipar által megszabott hatalom képviselöi. A területi tervezés új modelljeként megvalósítják a technológiának a mindennapi életbe történö harmonikus integrációját. Valóban utópisztikus társadalom képét jelenítik meg, a városlaboratóriumot, amelyben az aktorok szabadon oldódó és kötődő informális partnerségei és társulásainak kölcsönös megtermékenyítő hatásaként születnek az innovációk. Ezek az utópisztikus terek a társadalmi kísérletezés színterei, ahol az esztétikus természeti környezet és kimagasló életminöség miatt elmosódnak a munka és a szabadidő közti éles határvonalak, megterem a ,játszva alkotás" illúziója.

A szereplök tudatában vannak, hogy folytonosan megújuló, bizonytalan kísérletben vesznek részt, amelyben a siker saját személyes elkötelezettségük függvénye. Ez az oka a belső kommunikáció rendkívül fejlett szintjének. A technopolisz lakója privilegizált egyén, mivel részt vesz a jövő́t alakító „itt és most” megvalósuló döntések formálásában.

A technopolisz-modell a policentrikus döntési pontok megsokszorozásával az állam irányító funkciója helyébe az egymással kooperáló „szabad községek” képét lépteti, amelyekben minden megfelelö erőforrásokkal rendelkezö szereplö keresleti és kínálati oldalon is részt vehet a szolgáltatások cseréjében. A Grenoble-i technopolisz egyfelöl összehangolja a tudósok, politikusok, és várostervezők társadalomra vonatkozó vízióit, másfelől megtestesíti Le Corbusier vízióját, amelyben a város nagy parkként szerepel (az építész az agglomerációt zöld övezetnek képzelte) (Crow 1989). Hasonlóan Le Corbusier nézeteihez, ebben az utópikus rendben a tudósok a városhierarchia csúcsán helyezkednek el, akik racionalizáló cselekvésük által jólétet, rendet és szépséget hoznak a társadalom életébe. Azonban a technopolisz nem hasonlít Le Corbusier urbánus központként funkcionáló „Ragyogó Városához”, mivel olyan szuburbánus térként épült $\mathrm{ki}$, ahol a munka jelenti a legföbb örömforrást, s az oktatási intézmények és egyetemek az identitás hordozói az amerikai campus mintájára. A tudományos elit számára kialakított és elkülönített racionális térhasználattal jellemezhetổ szuburbánus pólus a hagyományos város alternatívájaként szolgál, más- 
A fél évszázados múltú francia területfejlesztés (aménagement du territoire) és egy középváros bemutatása a változó paradigmák fókuszában. - Tér és Társadalom 23. évf. 2009/1. 167-180. p. TÉT XXIII. évf. 2009 - 1

Kitekintö

felől pedig körülzárja és elszigeteli a jövő zálogát jelentő elit társadalmi csoportot. Ez az utópia annyiban is leképezi Le Corbusier eszményét, amennyiben a város, mint eszköz szerepel. Le Corbusier utópiájában a racionális térbeli elrendezés a leghangsúlyosabb elem, a geometria tükröződésének mértéke pedig a városnak a hierarchiában való helyét tükrözi (Crow 1989). Az idealista építész-várostervező elképzeléseihez hasonlóan a technopolisz egyúttal kifejezi a tudományos racionalitás által uralt utópisztikus társadalmi rend megvalósításának igényét is.

\section{A Grenoble-i innovációs pólus}

Az innovációs kultúra jelentőségét mutatja a Grenoble-i innovációs pólus három kiemelt szektora, a mikro-nanotechnológiák és a szoftverek, a biotechnológia és élettudományok, valamint az alternatív energiaforrások. A Minalogic (MicroNanotechnologies et Logiciel Grenoble-Isère Competitivité) - a 2005-ben kijelölt hat nemzetközi versenyképességi pólus egyike - az a pólus, amely leginkább megfelel a versenyképesség alapját jelentő folyamatos innováció kritériumának. Két klaszter alkotja a pólust: a Micro-nano (új elektronikai anyagok) és az EmSoc (szoftverek). 2006-os adatok szerint 27 gazdasági tevékenység, 46 intézmény és 11 ezer foglalkoztatott alkotja a pólust (amely a Rhône-Alpes régió foglalkoztatottjainak 7\%-át, Isère megye foglalkoztatottjainak 22\%-át jelenti). Két évvel megalakulása után 115 tagja volt: 79 vállalat, 13 kutatóközpont és egyetem, 16 helyi közösség és 6 gazdaságfejlesztési szervezet (pl. AEPI - Grenoble-Isère Gazdasági Fejlesztési Ügynőkség). Működése során 113 kutatási projektet jelölt meg és 73 projektet finanszírozott 315,5 millió euró értékben (www.grenoble-isere.com).

A 46 intézmény egyharmad részét a nagy elektronikai alkatrészeket gyártó cégek, másik harmadát a fejlesztő partnerek alkotják, kiemelten a szoftverfejlesztő cégek. Ezek a kisvállalkozások gyakran a pólus más nagyobb cégeinek alvállalkozói. A kereskedelmi intézmények (10-20\%) termékértékesítéssel és a fejlesztési források felkutatásával foglalkoznak. A nem kooperáló intézmények az összes szereplő ötödét alkotják. Ezek nagyrészt nemrégiben alakult kisebb cégek, amelyek még nem képesek együttmüködési kapcsolatok kiépítésére, és a közös fejlesztési projektekben sem vesznek részt, mivel szabadalmak híján nem látnak bennük megtérülési lehetỏséget. A két alapvetó tevékenység (elektronikai alkatrészek és szoftverek) az alkalmazottak felét foglalkoztatja, közülük is nagyobb számban vannak jelen az alkatrészek gyártói. $\mathrm{Az}$ intézmények fele kevesebb, mint 100 fót foglalkoztat, vagyis az összfoglalkoztatotti létszám 7\%-át, míg a pólus hét legnagyobb intézménye a foglalkoztatottak 59\%-át koncentrálja. Míg 1996 és 2006 között Grenoble térségében a foglalkoztatottak létszáma $13 \%$-kal nỏtt, a póluson belül ennél sokkal eröteljesebb növekedés volt tapasztalható (elektronikai ágazatok: 160\%-os; szoftverfejlesztés: 68\%-os).

$\mathrm{Az}$ együttmủködési kapcsolatok tỏbbségét a mikro-nanotechnológiák és a szoftver intelligencia területén a hiányzó kompetenciák megszerzése motiválja. Az intézmények a pólusban való részvétel nyújtotta elönyök közül a legfontosabbnak az emberi 
és anyagi erőforrásokhoz való hozzájutás lehetőségét, valamint a piaci igényekhez rugalmasan alkalmazkodó belső struktúra kiépitését tekintik.

Az állami segélyek jelentősen hozzájárultak a gazdasági és innovációs tevékenységek, partnerkapcsolatok elindításához és bővítéséhez. (Ezt mutatja, hogy 2002 és 2005 között a pólus belsejében az üzleti forgalom megduplázódott, a tevékenységek pedig 50\%-kal növekedtek). A szoftverfejlesztő cégek a fejlesztési segélyek fö haszonélvezői, ezek gyakran inkubátorokból kikerült cégek. A szereplök ellenben a termelékenység növekedéséhez, a termékek forgalmazásához nem kapnak támogatást. Az innováció legnagyobb akadálya a pénzügyi eszközök hiánya. A kis cégek önerőből való fejlesztési lehetőségei korlátozottak, a pólus pedig nem képes biztosítani tevékenységük folyamatos finanszírozását. Az innováció másik korlátja az innovációs termékek iránti kereslet nagyfokú bizonytalansága, az együttmüködő partnerek hiánya, a nagyobb cégek számára pedig az innováció tetemes költségei.

A pólus léte alátámasztja azt a nagyon fontos tényt, hogy a területi versenyképesség kritériuma a ,kicsi szép” helyett az „együtt szép” fogalmat részesíti elönyben. Mivel az egyes szereplók önmagukban nem, csupán a hálózatok (akár városi, akár ipari) alkalmasak a nemzetközileg látható kritikus tömeg elérésére, a területfejlesztési céloknak e hálózatok müködésén keresztül kell megvalósulniuk. Bár a Grenoble-i versenyképességi pólusok azt mutatják, hogy a kritikus tömeg és a koncentráció nélkül nem létezhet innovációs pólus, a francia versenyképességi pólus programban ezek mégsem alapvető feltételei a részvételnek. Léteznek pólusok, amelyek sokkal lazább szervezettségủek, tevékenységeik $\mathrm{K}+\mathrm{F}$ tartalma kevésbé jelentős, ezért hatékonyságuk inkább függ gazdasági szervezettségük fokától, mintsem a kritikus tömeg elérésétől (ezt illusztrálja a legtöbb helyi termelési rendszer).

\section{Összefoglalás}

Az állami területfejlesztési politikának a 21. század hajnalán számos kihívással kell szembenéznie (vidéki térségek elnéptelenedése, a városok túlzsúfoltsága, Franciaország szerepe Európában, île de France és a metropoliszok szerepe, decentralizáció, foglalkoztatás). Míg a klasszikus területfejlesztési politika - a regionális politika fogalmának szinonimájaként - az állami grandiózus gazdaságpolitika céljait kiszolgáló eszközként, majd tủzoltóként működött évtizedeken át, a területi tervezés csekély szerephez jutott (a városfejlesztési dokumentumokon kívül). A tradicionálisan kettészakadt országok (Párizs és a francia sivatag, - Budapest és vidéke) a globalizáció kontextusában nem értelmezendő fogalmak, hiszen e térben a nagyvárosi kapcsolatok és globális hálózatok mentén polarizálódik a tér. Az európai városversenybe bekapcsolódni esélyes nagyvárosok (pl. Lille, Lyon, Marseille, Toulouse) azok a régiócentrumok vagy befolyásos alközpontok, amelyek nagyrészt lefedik a hatvanas években Párizs ellenpólusaiként kijelölt városokat. 
A fél évszázados múltú francia területfejlesztés (aménagement du territoire) és egy középváros bemutatása a változó paradigmák fókuszában. - Tér és Társadalom 23. évf. 2009/1. 167-180. p.

A globális térben a településhálózat hierarchikus felépítésủ piramismodelljét felváltó hálózatos gazdaságban (a „,szigetcsoportok gazdaságában”), a perifériák és lakóik végleges leszakadásának veszélye, a problémákat átfogni képes transzverzális intézmények hiánya jelentik a legföbb megoldásra váró problémákat. A periférikus fekvésü városok közül a Grenoble-i technopoliszra fókuszált a jelen tanulmány, illusztrálva a technopolisznak a hagyományos centrum-periféria viszonyokat átalakító funkcióját, új területrendezési modellként való megjelenését.

$\mathrm{Az}$ állami gazdaságpolitikai célok (területi versenyképesség, innovációs hátrány felszámolása, csúcsipari fejlesztések) és a helyi gazdaság élénkítésére vonatkozó városfejlesztési célok párhuzamos megvalósításának példảja a MINALOGIC versenyképességi pólus. A pólusban való részvétel Grenoble számára középváros rangja ellenére erösíti a nagyvárosiasodás jegyeit (döntési központok jelenléte, stratégiai munkahelyek száma), nemzetközileg is elismert csúcsipari klaszter hírnevét, ezzel kiutat jelenthet középvárosi stagnálásából, periférikus helyzetébỏl adódó elzártságából.

A Grenoble-i sikertörténet jól példázza, hogy nem csak MEGA lehet versenyképes központ. Az emberi találékonyság és ebböl fakadóan az innovációs kultúra évszázados múltja, a felsőoktatás és az ipar szimbiózisa, a külfơldi szakképzett munkaerő nagyarányú jelenléte, valamint a tudományos elit városvezetésben kiemelkedő szerepe állt a nemzetközi hírnevü csúcsipari klaszter fejlödésének hátterében. Ez a fejlődés az állami és helyi fejlesztéspolitikai célok találkozása nélkül azonban elképzelhetetlen lett volna.

A központi és helyi fejlesztéspolitikai célok koherenciája lehet a jövőbeni fejlődés záloga a magyar településhálózat szereplöi számára is. A településhálózat kirívó egyenlötlenségeinek felszámolását a Perroux elméletére épülö központilag vezényelt növekedési pólus program nem valósította meg, a fordista növekedés kontextusában megvalósult ipari dekoncentrációs müveletek ellenére. Azok a vidéki városok válhattak - nagyrészt öneröböl - valódi növekedési centrummá, amelyek korukon túlmutató jövőre vonatkozó határozott koncepcióval és érdekérvényesítő képességgel, a város fejlesztési profilját megszabó szakembergárdával rendelkeztek (Grenoble esetében ez a tudományos technokrata elit), emiatt a központi forrás elnyerése számukra következmény volt, nem pedig ok. Grenoble esetében az autonómiára törekvő helyi tudományos-politikai-felsőoktatási szereplök arany háromszöge jelentette a sikeres városfejlődés zálogát a 20 . század végéig. Azonban a 21. századra felerősödő kihívások, az interkommunális szervezödések igénye, a közös területpolitikai célok megvalósításának érdekében indított nagyvárosi együttmüködési projektek a városi kereteken túlmutató együttmüködési hajlandóságot, a versengésen alapuló városi kapcsolatok felszámolását kívánják meg. Emiatt a város identitását a szükebb határain túlmutató funkciói: az interkommunális szervezetekben való részvételének mértéke, régiójában betöltött funkciói s a több régiót átfedỏ nagyvárosi hálózatokban való szerepe fogja befolyásolni. 


\section{Jegyzetek}

${ }^{\mathrm{l}}$ Lille, Nancy-Metz, Lyon, Marseille, Toulouse, Nantes, Bordeaux, Strasbourg.

${ }^{2}$ A strasbourgi egyetem mágneses fakultása Louis Néel Nobel dijas professzorral az élen 1939-ben a Grenoble-i Joseph Fourier müszaki intézetbe költözött. Végleges letelepedésük oka, hogy a CNRS megalapítja a Fémek Elektrosztatikája és Fizikája Laboratóriumot, ahol az Oktatási Minisztérium posztokat teremt. 1955-ben Néel ösztönzésére az Atomenergiai Kormányközi Bizottság (CEA) létrehozza Grenoble-ban a nukleáris kutatások központjaként funkcionáló $C E N G$-t, amely a város tudományos fejlődésének meghatározó szereplöje lesz (több mint 40 innovatív vállalkozást hozott létre, 3000 kutatót és 150 kutatócsapatot fog össze). Néel professzor szlogenje: „Az ipart szolgálni a jövő elökészítésében". (Frappat 1997, 35.)

\section{Irodalom}

Asheim, B.T. (1996) Industrial districts as 'learning regions': A condition for prosperity?" - European Planning Studies. 4. 379-400. o.

Crow, D. (1989) Le Corbusier's Postmodern Plan. - Theory Culture Society. 6. 241-261. o.

Frappat, P. (1997) Grenoble, métropole des sciences. Editions Glénat, Paris.

Goigou, J.L. (2000) Aménager la France de 2020. www.lesrapports. ladocumentationfrancaise.fr

Grossetti, M. (1999) Genèse de deux systèmes urbains d'innovation en France: Grenoble et Toulouse. Réalités Industrielles, Annales des Mines, ESKA Paris. 68-72. 0.

Merlin, P. (2007) L'aménagement du territoire en France. La documentation Française, Paris.

Parr, J.B. (1999a) Growth-pole Strategies in Regional Economic Planning: A Retrospective View. Urban Studies. 7. 1195-1215. o.

Parr, J.B. (1999b) Growth-pole Strategies in Regional Economic Planning: A Retrospective View. Urban Studies. 8. 1247-1268. o.

Rouban, L. (1994) Les politiques technologiques entre centre et périphérie: l'expérience des technopôles. - International Political Science Review. 15. 43-59. o.

Theys, J.-Bain, P. (2007) Contributions à la réflexion sur les pôles de competitivité. www.rechercheinnovation. equipement.gouv.fr/IMG/pdf/CPVS22-1_cle527b83.pdf

Vanier, M. (2005) Grenoble: quelle alliance métropolitaine? - Territoires 2030. 159-172. o.

Veltz, V. (1996) Mondialisation, villes et territoires : une économie d'archipel. PUF, Paris.

Wakeman, R. (2003) Dreaming the New Atlantis: Science and the Planning of Technopolis. - Osiris. 18. 255-270. o. 